\title{
Ethno Cultural Concept of Family Life in Malaysian Literature in English
}

\section{Murooj Fareed Majeed}

English Language and Literature, Taras Shevchenko National University of Kyiv, Ukraine Email:murooj_farid@yahoo.com

Abstract: A family involves two or more persons who live in the same household and are related through blood, marriage, or adoption. Family is "a social group branded by a common home, economic collaboration, and reproduction. It includes grown-ups of both genders, at least two of whom sustain a socially approved sexual relationship, and one or more children, own or adopted, of the adults living together(Alakavuklar, 2009).The study is going to examine the concept of family in term of father/mother, father/children, mother/children binary opposition between three main ethnic groups in Malaysia (Malay, Chinese, Indian) through Malaysian novels in English: 'The Rice Mother', 'Evening Is the Whole Day', 'Green Is the Color', and 'The Garden of Evening Mist'.

Keywords: ethno cultural; family life; Malaysian literature

\section{Introduction}

Binary oppositions are consistently in culture studies when one is investigating connections between various groups of individuals. Even though these appear as though minor recognizing marks, however, what makes them binary opposition contrary energies is the idea that they can't exist together. Since binary opposition is under the grand roof of structuralism, the understanding of structuralism is paramount. Structuralism, as Klages [2006; 31] puts it, "a perspective that attempts to locate the essential fundamental units or components of which anything is made. Claude Levi-Strauss is the principal researcher of structuralism. He made investigations on a kinship. He recommended that if anybody attempts to get a kinship, it can't be comprehended through examining a solitary unit family that comprises of father, mother, and their kids. He clarified that a solitary unit family is a unit of a more significant connection framework that is commonly considered as auxiliary. A kinship must be comprehended when it will be treated as a piece of the bigger entirety. The family relationship is to be examined with regards to this more prominent structure.

This can be as far as the more distant family where granddads, uncles, aunties, and others are included [Mohamad Diah \& Hossain ,2014].Jacques Derrida (1930-2004) investigated structuralism as a strategy to comprehend the way of thinking of language and mysticism of communication, including sign's system. Derrida's perspective affected deconstructive scholarly analysis. One of the strategies that take the inside stage is an investigation of binary opposition, for example, nature/culture, and male/female" [Godavarthy, 2017: 59]. Deconstruction hypothesis has its birthplace in structuralism; this has any kind of effect as far as the part of a translation of writings, according to him, binary pairs' were on no event equivalent. However, there are different examinations on binary opposition, One of the most well-known Binary Oppositions predominant in our general public is that of the Male/Female division that plans to set up men as the more strong, grounded, pioneering and widespread sexual orientation while assigning the female as a frail, credulous and shallow-minded Khair Ul Bashar1, Alam Zeb (2019). Khachmafova, Zayneta R, et al. (2015). Alami, Manizheh (2016). Haleem, Shamaila (2014). Michael Flood and Bob Pease (2005).The binary appeared right now father versus mother, parents versus youngsters. 


\section{Disucssion}

\subsection{Analysis of the Family}

Father is depicted in evening as the whole day as the higher position in the family, he should provide sources Tata regularly said: We're lucky to live here. It's the best place on earth, none of India's problems. Peace and quiet and perfect weather. Just work hard and the world could belong to you here. By the time Tata retired, in 1956, he owned a shipping company that rivaled his old employer's. A wry sun was setting with a vengeance on the British Empire. Tata decided to buy himself a house that would declare his family's stake in the new country. A great house, a grand house, a dynastic seat. He would leave Penang and look for such a house in Ipoh, far away from the dockyards, hilly, verdant, the perfect place to retire $(5, \mathrm{p} 18)$.

The text shows the support and sacrifices of parent for having a better life to their children. Tata, who immigrates from India to Malaysia, leaving his life back there, for the reason of having better opportunities to his family. The text shows fathers role in Malaysia who provide sources for their children daily needs, through Tata who, decides to move into another place and buy new big house that could satisfy his family need .Moreover, the text shows that Malaysian fathers show their love to their children through supporting them instrumentally "Insuring a good future for them" while, saying emotion words like "I love you" is not in their priorities.

While in Green is the colour, a father is depicted as a caring person and the protector of the family

Her father said to her when she returned,

Where have you been?

Why are you back so late?

You know it's dangerous to go about alone (2, p36).

Fernando highlights the role of the father as the care taken thus when Sara arrives home late, her father discusses the matter with her 'You know it's dangerous to go about alone'(2,p36).Sara's father takes the attitude of a worried parent through 1)directing his daughter for not coming home late and providing the anesthesia about how dangerous to be out late for a woman.Moreover, Fernando shows how Malay fathers are afraid of letting their daughters going out alone, consider the girl as immature, weak , and can't protect herself. Another text " Lebai Hanafiah instinctively knew he was going to beasked for her hand, and to avoid having to refuse him, hurriedly arranged for her to go to America ,for further studies"(2,p36). That shows the father role as caretaker and a worried parent, when he directs his daughter to travel abroad "for further studies" In order to protect her from Panglima, a political secretary for the minster of home affair in Malaysia, who desires Sara, although "The news of her marriage to Omar didn't diminish Panglima's desire for her "(2,p36). Sara's father takes the attitude of a protective parent by instructing his daughter to travel to America for further studies.

While in The Rice Mother father depicts the role of passive parent: Father was silent as he usually was. Ayah took a passive role in the family. Thus, when the Japanese occupy Malaysia they used to take everything nice, one day when Ayah was outside chatting with his friend the Japanese came and took his daughter Mohin How dare he leave us to fend for ourselves against Japanese soldiers while he sat gossiping with that doddering old Sikh security guard outside the Chartered Bank building?As when he gets home he asks with a calm voice 
about his children, which made Lakshmi, his wife becomes angrier about this kind of careless father Where are the children?' he asked, so quietly that I had to raise my eyes from his collar and look into those small, frightened eyes. 'They have taken Mohini away,' I said dully and as suddenly as my anger had come, it dissipated. I felt lost and longed for a husband who would take my burdens away for one hour. Someone who would make things right again. As for careless father, he gives his son, lakshmnan money to bet with it although he knows it's wrong which made his wife always fight with him because of his behaviour and her unsatisfaction with him as a father and a husband I had just argued with Ayah because I had seen him slipping money into Lakshmnan's hands. Making me look like a monster and giving our son the impression that gambling was OK. However, being a passive and careless father is something unaccepted by the country, and he became like a one who is not respected by his wife and his children. My mother said that when I was born she cried to see that I was only a girl, and my disgusted father disappeared to make more pickled lies, returning two years later still roaring drunk.

As for the mother role, it is shown as a dependent and weak person in all selected novels. How can I tell my beloved child there is nothing to forgive, only love to be given. I understand her grief completely. With my lips, I tried to tell her so. I whispered the words and she bent her head closer straining to hear $(2, \mathrm{p} 90)$.

The text illustrates the weak role of the Malay mother in the family. Thus, when Sara was assaulted and raped by Panglima, her mother's part was vibrant, she could not do anything to defend or take the right of her daughter, she uses the words only to console her daughter's sorrow and recaps her about the painful and memorable scene, although, this is the only thing she can do to her daughter. Fernando highlights the image of the mother in a patriarchal society and her weak role that makes her give only love and consolation to her daughter instead of urging her to fight for her right. The following texts show how the mother depends on the man in her life, thus Lakshmi and her mother depends on their father and later Lakshmi depends on her husband to provide her with a source 'My mother and I suffered because my father did not bother to send us money'. In another occasion, which signifies the position of women as dependent to her husband, is appeared in " The Rice Mother" when Mui Tsai life, as an image of a Malaysian woman who sits home waiting for her man return from work of long hard day to take care of him and "massage him "(p42) and when Ratha another character, a living example for malaysian woman who is happy when cooking and cleaning for the man she loves "It was my joy to cook and clean for him"(356).

On the other hand, Samarsan elicits a crucial element in "Evening Is The Whole Day" that Malaysian society with all its ethnic groups always put the blame on the woman, even if she is not mistaken, it is better for her to keep silent in order to protect her interests by not openly exposing issues that could jeopardize how people see them. For instance, in so far as Amma had the option of informing her husband about the suffering she was enduring under Paati, she resolves to keep her sufferings as well-protected secrets. According to Amma, exposing the mistrust between her mother-in-law and her would imminently backfire against her. This could have a resultant effect of influencing her husband to view her from a negative dimension

Although depicting the mother's weak role in the novels; mother is the main foundation of transmitting their culture and language from one generation to another, as the mother is responsible for caring for her children at home that's why Lakshmi teach her children and grandchildren her culture and language I decided that I would teach Dimple our culture and teach her to speak Tamil. It was her heritage and her right. I began to tell her our 
family stories for there were many things I wanted to leave in her care. Rani had her Western ways about her. She refused to teach her children their mother tongue,Rani characterizes the opposite of this woman, as she recognizes eastern civilization and adopts the Western language and culture and tries to teach her children the same thing. And this made her forbidden by the rest of her kinsfolks as being a conspirator to her role as a carrier of culture and ancestral language. Rani always sees herself above others. She marries lakshmnan ,an Indian and Malay man, the son of Lakshmi and Ayah, she deceives Lakshmnan to marry her by seducing to pay him a good dowry for she was an ugly woman, which made Lakshmnana marries her, but the fact she was always against Lakshmnan mother, since she doesn't want to learn her children a Tamil language and principles while Lakshmi is against, thus when Rani gives birth to her son Nash ,Lakshmi give him a gold ring like a traditional custom between Indian grandmother to hand her grandson a gold ring, Rani refuses it and take it off from her baby as shown in the text below:

She had named him Nash. She was very proud of him .I brought him the usual gold rings, bangles and anklets that one gives to a grandchild. I put them all on his little body with my own hands and she took them all off and placed them in the pawnshop as soon as she left the hospital.

As for the role of sons toward their parents in Malaysian novels in English. Sons are compliant to their father thus when Tata's father directs him to study "Study hard. Study hard and you won't have to be a coolie like me, Study hard and the world will be yours. You could be a rich man. With a bungalow and servants".Tata listens carefully to his father and gets a good position as a clerk in a company and so Tata studied hard enough to get himself a clerk's position. Moreover,Tata's father used to tell his son to work hard and the world will belong to him .Thus, The following text shows how son imitates his father words: - Tata regularly said: We're lucky to live here. Peace and quiet and perfect weather. Just work hard and the world could belong to you here.Thus Tata's father use to tell him to work hard the world belongs to you, which shows that son should emulate their father words and pass it from father to son as a tool of stimulating

Thornton and Lin (1994) indicates that filial piety requires that children or grandchildren respect and care for their parents or antecedents Thus when the wife went out shouting at the boys in the garden for making noise. The boys "hung their heads in shame "(4, p176) then "kissed her hand in apology" (4, p176). The basic Chinese family structure is young respecting adults. Chinese always teach their children to be respectful and obedient. The person who respects his parent will be respected by society even if he is a thief. Society will pardon as stated in the text" if one were judged to be filial to one's parents" (1, p127) society "will find it easier to forgive"(1, p127).

In Rice Mother, the son imitates his parent's features Of course, Lakshmnan understood. He was not my mother's son for nothing. The rest he would get in Never-Never Land. She held the bulky envelope out. Take the cash, waive the rest. He was being cheated. Lakshmnan is like his mother's features and purpose, she wanted to marry a rich husband to live a rich life but it turned that she was cheated by her husband who was a less fortunate servant, but not rich, which made he do that to enable him to marry Lakshmi. Her son, Lakshmnan also has the same purpose as his mother. He also wanted to marry a rich girl and have deceived by the girl to turned that she is poor, the same for his mother Lakshimi who thought Aya was rich and married him.

Remarkably, male children are likely to copy the behaviours of their fathers while girls are likely to imitate the behaviours of their mothers. As shown in the following texts: 
a. Then came the day Mother could wait no longer. She sent a friend's son to find out what was happening to her first-born. He returned with the news that Lakshmnan had become a gambler.

b. I wanted him to kick the habit and I deeply resented his father's weak stance.

Aya's son, Lakshmnan becomes a seasoned risker when he grows up. As can be expected, most gamblers are typically deceitful individuals who use coercive ways of making things to shift into their side regardless of the effects of their actions on other people. This can be indicated by the words of Lakshmi that, "Lakshmnan's gambling habit had turned life into hell on earth for all of them" (4, p.233). In the end, Lakshmnan impoverishes his wife and children as a result of his compulsive lay bets that only siphon resources out of the family" I have been a terrible father.A headless father"(4,p304). It is possible to track such unprincipled mechanisms of deceptions to Lakshmnan's father, Aya, who deceived Lakshmi that he is a wealthy man as a way of winning her trust. Manicka wrote The Rice Mother as a means of strategically demarcating Malaysian history in a multigenerational style (4, p.303). This literary work of art revolves around an Indian Family based in Malaysia. The narration begins from the early 1920s where the major character referred to in the title, Lakshmi, is married off by her family to a man who is almost triple her age. Despite arriving at her marital home with high hopes of an optimistic life, Lakshmi is surprised when she discovers that the conceptions she had about her marital home were mere wishful thoughts. Lakshmi's husband absconds his duties as a father and a husband; thereby making her brings up the children all by herself. The manner that Lakshmi relates with her husband and mother-in-law shows the bigger picture of the Malaya society.

While the role of daughters toward their parents in Malaysian novels in English. Daughter is portrayed in the Rice mother as a weak .Daughter has no decision, this is shown by Rani as a weak daughter who has no decision for her marriage The truth is, between them all they forced me to marry Lakshmnan. At the same time, Rani married Lakshmnan for the sake of her brother, who show the bound relationship between sisters and brother as a strong relationship where sister can sacrifice herself for her brother in the end, I was forced to marry Lakshmnan for the sake of my brother who was suddenly and mysteriously enamoured with the spider's daughter. Marry him,' they all chorused. What could I do? Stand in the way? No, I sacrificed my shining dreams for my brother. So I married Lakshmnan.

Rani refers to Lakshmnan's mother as a spider and her brother to marry her daughter, the spider daughter,as he wishes to marry her ,for that Rani sacrifice herself and marry Lakshmnan to give her brother a chance to marry the woman he wants on the expanse of her happiness, the writer shows the relationship between in-laws ,although Rani doesn't like her mother in law she obliged to marry her son and live with them.

Manicka depicts the role of daughter successfully as weak and has no decision to choose her specialty to marry, study and work as Lakshmi chooses the study for her daughter Lalita: The years were passing but I just could not find a bridegroom for Lalita. With no qualifications, she wanted to train to become a nurse but I wouldn't hear of it. How could I let my daughter wash strange men in intimate places? No, no, such a dirty job was not for my daughter. I sent her to typing school but whenever she went for an interview, she was so nervous she couldn't stop making mistakes. I was getting desperate. If she had been a working girl, she might have found a husband, but with her looks and being unemployed even a dowry of twenty thousand only brought forth unsuitable men of suspect character. 
Lakshmi tries to find a husband for her daughter, which put the light on the significance of the active mother role in finding a husband for their daughter and the passive role of the daughter. Thus, when Lalita wanted to become a nurse, her mother refused and sent her to typing school. Although a nursing job considers as one of the good jobs in some countries, it is not desirable by some Malaysian families since it requires mixing and dealing with men, there is something the text shows, which is the importance of work to a woman to guarantee herself a good husband, which led suffers from thinking on the best job to choose.

Manicka mentions another role for daughter as a caring person who should stay home and take care of her grandparents Are you girls planning to leave me here all alone with my swollen feet and my crippled hands? What if I fall while you're out?' Grandma Rani cried peevishly. 'Please, Grandma Rani. I promise I won't keep Bella long. Just sit and wait for a little while, OK?'

\section{Conclusion}

To conclude the study shows that Malaysian parents take care of their children even when they are married still giving them money, which is their way to show their love instrumentally, for father role, he is considered as the higher position in the family, the caring and the one who provide sources to the family as a positive feature and in others, he takes the place as an uncaring, but at the same time the manuscript shows that being a careless is refused by Malaysian society which let them being unrespect by their children. As for a mother, she took the weak role in all novels, she depends on her husband to give her the money, but at the same time, she has the core role in raising her children inside the house and passes her culture and language to her children As for children, where Malaysian son in all ethnic group (Malay, Chinese and Indian) should be dutiful to their parents and do as they are instructed. Sons imitate their father's behavior and structures like Laksmnan who become like his father Ayah a loser and gambler. As for daughter, she is depicted also as an obedient to her parents, she has no decision to make for her study or sometimes to get married, but at the same time she is taking the place of a caring person who take care of her grandparents and the one who can sacrifice for her brother which show the bond between the brother and sister relationship in Malaysian families

\section{References}

Alakavuklar O.N. (2009). We are a Family _a Critical Organizational Discourse Analysis: International Journal of business and Manageme, 1(1) ISSN: 1309-8047 (Online)

Klages M. (2006) Literary Theory A Guide for the Perplexed. London: Continuum.

Mohamad D. N\& Hossain D. M. (2014) An Overview of the Anthropological Theories: International Journal of Humanities and Social Science, Vol. 4, No. 10(1).

Godavarthy M.(2017). Binary Opposition in Robert Frost's the Road not Taken

(1916) and the Armful (1928): International Journal of English and Literature (IJEL). № 7 (5). pp 57-64.

Khair U. B. \& Zeb A. (2019). Binary opposition of the characters in Steinbeck's Of Mice and Men: From Derridean perspective. International Journal of English Research. № 5(2) .P 51-54

Khachmafova Z R et el. (2015). Gender Features of Discourse in Women's Literature as a Reflection of Changes in the Modern Society, Mediterranean Journal of Social Sciences MCSER Publishing, Rome-Italy, № 6(3).

Haleem S. (2014).Challenging Gender Stereotypes: A Text Analysis of Qaisra Shehraz's Novel the Holy Woman, №74 (10). DOI: 10.7763/IPEDR 
Alami, M. (2016). Approaches to Gender Studies: A Review of Literature .Journal of Applied Linguistics and Language Research, № 3(3), 247-256

Flood M \& Pease B. (2005). Undoing Men's Privilege and AdvancingGender Equality in Public Sector Institutions, Policy and Society, № 24:4.P 119-138. DOI: 10.1016/ S14494035(05) 70123

\section{Reference to Novels}

Eng, Tan Twan. The Garden of Evening Mists. Rotterdam: Myrmidon Books, 2012. Print. Fernando, Lloyd. Green is the Colour. LandMark Books, 2011. Print.

Manicka, Ran. The Rice Mother. Belmont, CA: Wadsworth Publishing, 2013. Print.

Preeta Samarasan. Evening is The Whole Day. Houghton Mifflin, 2012. Print. 